\title{
Removal of acorns of the alien oak Quercus rubra on the ground by scatter-hoarding animals in Belgian forests
}

\author{
Nastasia R. Merceron (1,2,3), Aurélie De Langhe ${ }^{(3)}$, Héloïse Dubois ${ }^{(3)}$, Olivier Garin ${ }^{(3)}$, \\ Fanny Gerarts ${ }^{(3)}$, Floriane Jacquemin ${ }^{(3)}$, Bruno Balligand ${ }^{(3)}$, Maureen Otjacques ${ }^{(3)}$, \\ Thibaut Sabbe (3), Maud Servranckx ${ }^{(3)}$, Sarah Wautelet ${ }^{(3)}$, Antoine Kremer ${ }^{(1)}$, \\ Annabel J. Porté ${ }^{(1,2)}$, Arnaud Monty ${ }^{(3)}$ \\ (1) BIOGECO, INRA, University of Bordeaux. FR-33610 Cestas (France). \\ (2) BIOGECO, INRA, University of Bordeaux. FR-33615 Pessac (France). \\ (3) University of Liège - Gembloux Agro-Bio Tech. Biodiversity and Landscape Unit. Passage des Déportés, 2. \\ BE-5030 Gembloux (Belgium).E-mail: arnaud.monty@ulg.ac.be
}

Received on June 15, 2016; accepted on February 24, 2017.

This article is distributed under the terms and conditions of the CC-BY License (http://creativecommons.org/licenses/by/4.0)

Description of the subject. Quercus rubra L. is considered an invasive species in several European countries. However, little is known about its dispersal in the introduced range.

Objectives. We investigated the significance of animal dispersal of Q.rubra acorns on the ground by vertebrates in its introduced range, and identified the animal species involved.

Method. During two consecutive autumns, the removal of acorns from Q. rubra and from a native oak was assessed weekly in forest sites in Belgium. We used automated detection camera traps to identify the animals that removed acorns.

Results. Quercus rubra acorns were removed by wood mice (Apodemus sylvaticus L.), red squirrels (Sciurus vulgaris L.), rats (Rattus sp.), and wild boars (Sus scrofa L.). The two former are scatter-hoarding rodents and can be considered potential dispersers.

Conclusions. Dispersal of Q.rubra acorns in Western Europe by scatter-hoarding animals may help the species increasingly colonize forest ecosystems.

Keywords. Quercus rubra, Quercus robur, seed dispersal, Rodentia, invasive species, acorns, Belgium.

Prélèvement au sol des glands d'une espèce de chêne exotique (Quercus rubra) par des animaux accumulateursdisperseurs dans les forêts belges

Description du sujet. Quercus rubra L. est considéré comme une espèce invasive dans plusieurs pays d'Europe. Cependant, sa dispersion dans l'aire d'introduction est peu documentée.

Objectifs. Nous avons observé si les glands au sol étaient déplacés par les animaux et identifié les animaux impliqués.

Méthode. Durant deux automnes consécutifs, le prélèvement des glands de Q. rubra et d'une espèce de chêne indigène a été évalué chaque semaine dans différents sites en Belgique. Grâce à des pièges photographiques, les animaux prélevant des glands ont été identifiés.

Résultats. Les glands de Q. rubra ont été prélevés par le mulot sylvestre (Apodemus sylvaticus L.), l'écureuil roux (Sciurus vulgaris L.), le rat (Rattus sp.) et le sanglier (Sus scrofa L.). Les deux premiers sont des rongeurs accumulateurs-disperseurs, considérés comme disperseurs potentiels.

Conclusions. La dispersion des glands de Q. rubra en Europe occidentale par les animaux accumulateurs-disperseurs pourrait aider l'espèce à coloniser progressivement les écosystèmes forestiers.

Mots-clés. Quercus rubra, Quercus robur, dissémination des semences, Rodentia, espèce invasive, gland, Belgique. 


\section{INTRODUCTION}

Horticulture and forestry are major reasons for the introduction of exotic trees (Richardson \& Rejmanek, 2011). However, alien species may have negative ecological impacts (Vilà et al., 2011), and forests are not spared (Holmes et al., 2009). This situation may result in a conflict of interest between foresters and environmental managers (Dickie et al., 2014).

Effective propagule dispersal is essential for an introduced species to progress from naturalization to invasion (Richardson \& Rejmanek, 2011). In the case of animal-dispersed trees, disperser communities are likely to differ between the native and introduced ranges. A better understanding of seed dispersal in the introduced range is required to confirm the invasive potential of an alien tree species.

Native to North America, the northern red oak (Quercus rubra L.) was declared as invasive in several European countries (e.g. Woziwoda et al., 2014) and was shown to induce negative ecological impacts (e.g. Riepšas \& Straigyte, 2008). In its native range, it is dispersed by birds and rodents (Sork et al., 1983; Gribko et al., 2002). Scatter-hoarding rodents, through burying acorns and covering them with litter, act as significant dispersers and create favorable conditions for germination (García et al., 2002). In Europe, acorns of native oaks are consumed by animal species, some of which play a significant role in dispersal: birds, particularly the European jay (Garrulus glandarius L.), and scatter-hoarding rodents, especially wood mice (Apodemus sylvaticus L.) (Ouden et al., 2005). While the European jay plays a role in the dispersal of $Q$. rubra acorns above the ground (Myczko et al., 2014), little is known about the removal of $Q$. rubra acorns fallen on the ground in its introduced range (but see Bieberich et al., 2016). In our study, we asked:

- are acorns of Q. rubra moved away by animals on the ground?

- which animals are involved and among them, which can be considered scatter-hoarders?

- are acorns of Q. rubra and Quercus robur L. removed at the same rate?

\section{MATERIALS AND METHODS}

In autumn 2013 and 2014, four experimental sites (>3 km apart) were selected in southern Belgium (Table 1). All sites were mixed oak stands dominated by adult trees of $Q$. robur and/or $Q$. rubra. Acorns of both species were collected from the ground under fruiting trees and stored at room temperature. Acorns with obvious damages were discarded. Acorns were manipulated with latex.
At every site, four pairs of $28-\mathrm{cm}$ diameter plastic dishes $(10-20 \mathrm{~cm}$ apart) were randomly placed on the ground. One dish per pair contained 20 acorns of $Q$.robur, the other 20 acorns of Q. rubra. Every week, the acorns remaining in each dish were counted and removed, and the dishes were refilled with 20 acorns. When a dish was accidentally spilled, the data of the considered week were ignored. The experiment lasted from $04 / 10 / 2013$ to $08 / 11 / 2013$ and from $03 / 10 / 2014$ to 28/11/2014. Automated detection cameras (Cuddeback Digital, USA) were attached $30-50 \mathrm{~cm}$ high on the nearest trunk and pointed at the dishes. When movement was detected, the cameras took pictures every 5 seconds and recorded a video for 10 seconds. Seven and three cameras were available in 2013 and 2014, respectively, and were positioned in two sites (Table 1). Identification of recorded animals was made using mammal guide books (Quéré \& Le Louarn, 2011; Aulagnier et al., 2013). The videos allowed distinguishing acts of consumption from acts of collecting and scattering. We then classified the observed animals as pure consumers or scatter-hoarders of $Q$. rubra acorns, in agreement with the scientific literature regarding their feeding behavior.

For each Quercus species, the number of acorns removed from the dishes was converted to the proportion of acorns removed during one week, i.e. acorn removal rate. For each site, the mean acorn removal rate of the four dishes was calculated according to species and week, and arcsine-transformed. A mixed model with repeated measurements (proc. MIXED) was used to analyze the effects of species (fixed), week (random), site (random), and the interaction site $\times$ species on the mean acorn removal rate. Analyses were performed using SAS version 9.4 (SAS Institute Inc., USA).

\section{RESULTS}

Acorns from both species were removed on the ground by animals during all considered weeks at all sites.

Table 1. Location of the experimental sites and number of cameras used for the identification of animals (N) - Localisation des sites expérimentaux et nombre de pièges photographiques utilisés pour l'identification des $\operatorname{animaux}(N)$.

\begin{tabular}{lllll}
\hline Year & Site & Latitude & Longitude & N \\
\hline 2013 & Onoz & $50^{\circ} 28^{\prime} 58^{\prime \prime} \mathrm{N}$ & $4^{\circ} 40^{\prime} 39^{\prime \prime} \mathrm{E}$ & 4 \\
& Ferooz & $50^{\circ} 322^{\prime} 30^{\prime \prime} \mathrm{N}$ & $4^{\circ} 41^{\prime} 38^{\prime \prime} \mathrm{E}$ & 3 \\
& Grand-Leez & $50^{\circ} 35^{\prime} 16^{\prime \prime} \mathrm{N}$ & $4^{\circ} 47^{\prime} 16^{\prime \prime} \mathrm{E}$ & - \\
& Gembloux & $50^{\circ} 33^{\prime} 46^{\prime \prime} \mathrm{N}$ & $4^{\circ} 41^{\prime} 42^{\prime \prime} \mathrm{E}$ & - \\
\hline 2014 & Spy & $50^{\circ} 28^{\prime} 46^{\prime \prime} \mathrm{N}$ & $4^{\circ} 40^{\prime} 50^{\prime \prime} \mathrm{E}$ & 2 \\
& Floreffe & $50^{\circ} 66^{\prime} 07^{\prime \prime} \mathrm{N}$ & $4^{\circ} 42^{\prime} 37^{\prime \prime} \mathrm{E}$ & - \\
& Malonne & $50^{\circ} 22^{\prime} 55^{\prime \prime} \mathrm{N}$ & $4^{\circ} 49^{\prime} 42^{\prime \prime} \mathrm{E}$ & 1 \\
& Profondeville & $50^{\circ} 22^{\prime} 46$ ' N & $4^{\circ} 51^{\prime} 40^{\prime \prime} \mathrm{E}$ & - \\
\hline
\end{tabular}


Acorn removal rate did not differ between species in 2013. In 2014, acorns of Q. robur were preferred to acorns of $Q$. rubra. In both years, the acorn removal rate for $Q$. rubra increased from the beginning to the end of the monitoring (Table 2, Figure 1). Effects of site and interaction site $\times$ species were not significant (Table 2).

Based on camera traps, we identified four mammal species removing Q.rubra acorns. Wood mice (A. sylvaticus L.; 2013: 14 records; 2014: 0 record) and red squirrels (Sciurus vulgaris L.; 2013: 18 records; 2014: 0 record) were identified as consumers and scatter-hoarders. The pictures and videos distinctly showed them removing Q. rubra from the dishes (http://hdl.handle.net/2268/209505). Wild boars (Sus scrofa L.; 2013: 0 record; 2014: 4 records) and rats (Rattus sp.; 2013: 0 record; 2014: 7 records) were regarded as pure consumers of $Q$. rubra acorns because they were only seen eating acorns in the dishes, which was in concordance with the literature. No bird species were observed.

\section{DISCUSSION}

We demonstrated that mammals removed acorns of Q. rubra on the ground in Belgian forests. Wild boars and rats consume acorns but do not efficiently act as dispersers (Schley \& Roper, 2003; Quéré \& Le Louarn, 2011). In contrast, the scatter-hoarding rodents observed in our study, i.e., wood mice and red squirrels, are known for caching and burying native acorns (Wauters \& Casale, 1996; Ouden et al., 2005) and can therefore be considered potential dispersers of Q. rubra. Considering both years, scatter-hoarders

Table 2. Summary of ANOVA of the mean of acorn removal rate from dishes in 2013 and 2014 - Résumé de l'ANOVA de la moyenne du taux de prélèvement des glands dans les coupelles en 2013 et en 2014.

\begin{tabular}{lllrc}
\hline Source of variation & Year & d.f. & F or Z & p-value \\
\hline Species & 2013 & 1,30 & 7.52 & 0.0712 \\
& 2014 & 1,60 & 33.94 & 0.0011 \\
Site & 2013 & 3,80 & 0.95 & 0.3444 \\
& 2014 & - & - & - \\
Site $\times$ species & 2013 & 3,46 & 1.09 & 0.2772 \\
& 2014 & 7,74 & 1.36 & 0.1728 \\
Week & 2013 & - & 4.00 & $<0.0001$ \\
& 2014 & - & 5.29 & $<0.0001$ \\
\hline
\end{tabular}

For each variable and year, ANOVA results are presented using d.f. (degrees of freedom), F or Z statistics, and the corresponding $p$-value - pour chaque variable et année, les résultats de l'ANOVA ont été représentés par d.f. (les degrés de liberté), les statistiques $F$ ou $Z$, et la valeur $\mathrm{p}$ correspondante.
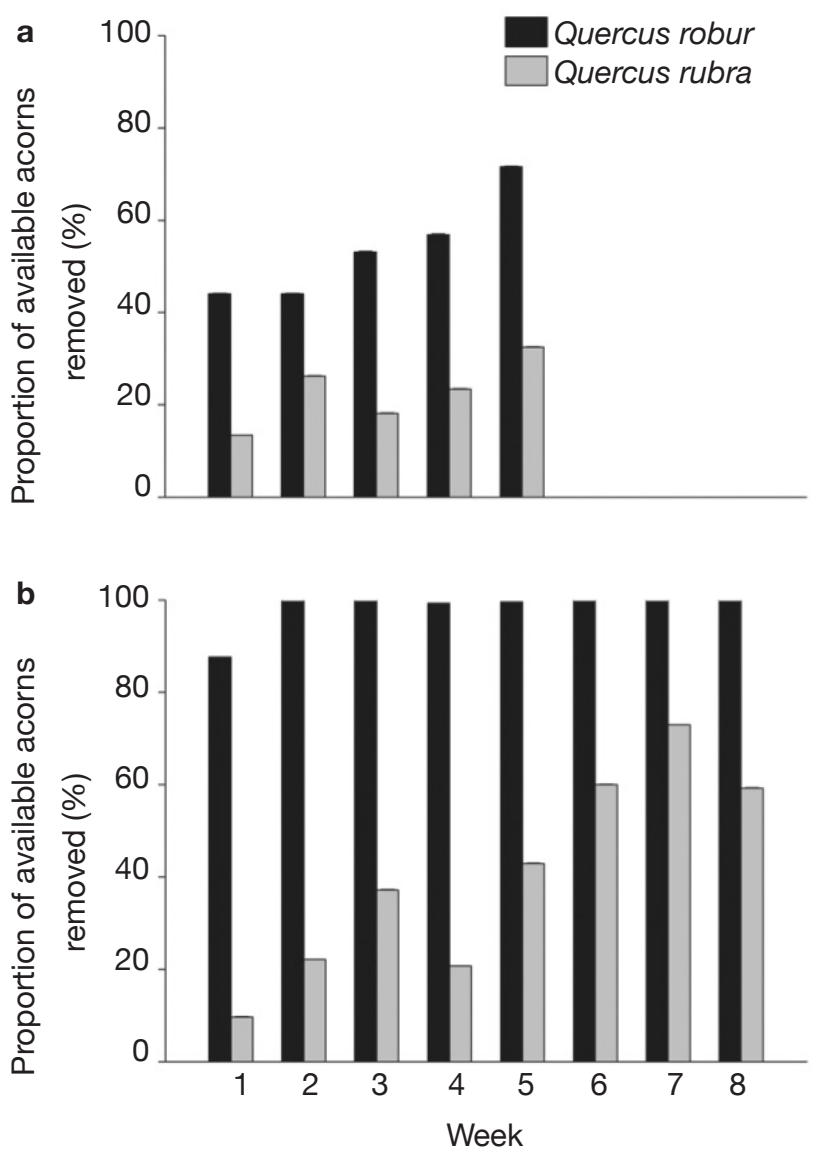

Figure 1. Proportion of $Q$. robur and $Q$. rubra acorns removed from the dishes by animals on the ground per week. Monitoring was performed over five weeks from October 4 to November 8, 2013 (a) and over eight weeks from October 3 to November 28, 2014 (b) - Proportion de glands de Q. robur et $\mathrm{Q}$. rubra prélevés dans les coupelles par les animaux au sol par semaine. Le suivi a été réalisé durant cinq semaines en 2013 du 4 octobre au 8 novembre (a) et durant huit semaines en 2014 du 3 octobre au 28 novembre (b).

Values represent the mean of the four experimental dishes for the four sites pooled together for each species and week $(\mathrm{n}=$ 16) - Les valeurs représentent la moyenne des quatre coupelles pour les quatre sites regroupés ensemble pour chaque espèce et chaque semaine $(n=16)$.

were recorded three times more frequently than pure consumers.

Across the two years, the acorn removal rate was higher for $Q$.robur than for Q. rubra. This can be attributed to the habits of the animals, as well as intrinsic properties of acorns. Quercus rubra acorns contain more fat than $Q$. robur acorns but have higher levels of tannins, known as chemical defenses that induce a bitter and astringent taste (Shimada \& Saitoh, 2006). In the native range, high tannin levels render Q. rubra acorns less palatable than other oak species 
and protect the embryos from consumption and subsequent damage (Steele et al., 1993).

Major et al. (2013) suggested that the dense regeneration of seedlings beneath red oak trees was related to the absence of seed movement on the ground. Our results indicate that a significant proportion of Q. rubra acorns, even if not preferred over native acorns, may be dispersed on the ground by scatter-hoarding rodents. Generally, scatter-hoarding rodents disperse intact or partially eaten acorns over areas approximately ranging from $100 \mathrm{~m}^{2}$ (wood mice) to 15 ha (squirrels) (Perea et al., 2011; Quéré \& Le Louarn, 2011). Potential dispersal distances can thus vary from a few meters to hundreds of meters according to the species and number of repeated dispersal actions (Perea et al., 2011).

\section{CONCLUSIONS}

Scatter-hoarding animals, though they do not seem to prefer northern red oak acorns over native oak acorns in Western Europe, may help the species increasingly colonize forest ecosystems through acorn movement on the ground.

\section{Acknowledgements}

The authors would like to thank Thierry Kervyn for access to Onoz site and Alain Licoppe for the loan of camera equipment. This study has been carried out with financial support from the French National Research Agency (ANR) in the frame of the Investments for the future Program (ANR-10- IDEX-03-02); and from the University of Liege in the frame of the "Fonds spéciaux pour la recherche".

\section{Bibliography}

Aulagnier S. et al., 2013. Mammifères d'Europe, d'Afrique $d u$ Nord et du Moyen-Orient. Paris : Éditions Delachaux et Niestlé.

Bieberich J., Lauerer M. \& Aas G., 2016. Acorns of introduced Quercus rubra are neglected by European Jay but spread by mice. Ann. For. Res., 59(1), 249-258.

Dickie I.A. et al., 2014. Conflicting values: ecosystem services and invasive tree management. Biol. Invasions, 16(3), 705-719.

García D., Bañuelos M.-J. \& Houle G., 2002. Differential effects of acorn burial and litter cover on Quercus rubra recruitment at the limit of its range in eastern North America. Can. J. Bot., 80(10), 1115-1120.

Gribko L., Schuler T. \& Ford W., 2002. Biotic and abiotic mechanisms in the establishment of northern red oak seedlings: a review. Newtown Square, PA, USA: U.S. Department of Agriculture, Forest Service.
Holmes T.P. et al., 2009. Economic impacts of invasive species in forests. Ann. N.Y. Acad. Sci., 1162(1), 18-38.

Major K.C. et al., 2013. Regeneration dynamics of nonnative northern red oak (Quercus rubra L.) populations as influenced by environmental factors: a case study in managed hardwood forests of southwestern Germany. For. Ecol. Manage., 291, 144-153.

Myczko Ł. et al., 2014. Predation and dispersal of acorns by European jay (Garrulus glandarius) differs between a native (pedunculate oak Quercus robur) and an introduced oak species (northern red oak Quercus rubra) in Europe. For. Ecol. Manage., 331, 35-39.

Ouden J. den, Jansen P.A. \& Smit R., 2005. Jays, mice and oaks: predation and dispersal of Quercus robur and Q. petraea in North-Western Europe. In: Forget P.M., Lambert J.E., Hulme P.E. \& Vander Wall S.B., eds. Seed fate: predation, dispersal and seedling establishment. Wallingford, UK: CABI, 223-239.

Perea R., Miguel A.S. \& Gil L., 2011. Acorn dispersal by rodents: the importance of re-dispersal and distance to shelter. Basic Appl. Ecol., 12(5), 432-439.

Quéré J.P. \& Le Louarn H., 2011. Les rongeurs de France : faunistique et biologie. Versailles, France: Éditions Quæ, 311.

Richardson D.M. \& Rejmánek M., 2011. Trees and shrubs as invasive alien species - a global review. Divers. Distrib., 17(5), 788-809.

Riepšas E. \& Straigyte L., 2008. Invasiveness and ecological effects of red oak (Quercus rubra L.) in Lithuanian forests. Baltic For., 14(2), 122-130.

Schley L. \& Roper T.J., 2003. Diet of wild boar Sus scrofa in Western Europe, with particular reference to consumption of agricultural crops. Mamm. Rev., 33(1), 43-56.

Shimada T. \& Saitoh T., 2006. Re-evaluation of the relationship between rodent populations and acorn masting: a review from the aspect of nutrients and defensive chemicals in acorns. Popul. Ecol., 48(4), 341352.

Sork V.L., Stacey P. \& Averett J.E., 1983. Utilization of red oak acorns in non-bumper crop year. Oecologia, 59(1), 49-53.

Steele M.A., Knowles T., Bridle K. \& Simms E.L., 1993. Tannins and partial consumption of acorns: implications for dispersal of oaks by seed predators. Am. Midland Nat., 130(2), 229.

Vilà M. et al., 2011. Ecological impacts of invasive alien plants: a meta-analysis of their effects on species, communities and ecosystems. Ecol. Lett., 14(7), 702-708.

Wauters L.A. \& Casale P., 1996. Long-term scatterhoarding by Eurasian red squirrels (Sciurus vulgaris). J. Zool., 238(2), 195-207.

Woziwoda B., Kopeć D. \& Witkowski J., 2014. The negative impact of intentionally introduced Quercus rubra L. on a forest community. Acta Soc. Bot. Pol., 83(1), 39-49.

(20 ref.) 